\title{
The murine gene encoding parathyroid hormone: genomic organization, nucleotide sequence and transcriptional regulation
}

\author{
B He, T K Tong, F F-T Hiou-Tim, B Al-Akad ${ }^{1}$, H M Kronenberg ${ }^{1}$ and A C Karaplis \\ Division of Endocrinology, Department of Medicine, SMBD-Jewish General Hospital, Lady Davis Institute for Medical Research, McGill University, \\ 3755 Côte Ste-Catherine Road, Montréal, Québec H3T 1E2, Canada \\ ${ }^{1}$ Endocrine Unit, Massachusetts General Hospital, Boston MA 02114, USA
}

(Requests for offprints should be addressed to A C Karaplis; Email: akarapli@ldi.jgh.mcgill.ca)

\begin{abstract}
The type 1 parathyroid hormone receptor (PTHR1) binds, with equal affinity, two ligands with distinct biological functions: PTH, the major peptide hormone controlling calcium homeostasis, and the paracrine factor, PTH-related peptide (PTHrP), a local regulator of cellular proliferation and differentiation. To clarify the complexity of possible interactions between two distinct ligands, PTH and PTHrP, and their common receptor in the intact organism, and to identify as yet unrecognized roles for PTH in normal physiology, we have cloned and characterized the structural organization, nucleotide sequence and transcriptional regulation of the murine gene encoding PTH. One recombinant clone isolated from a mouse genomic library contained $14 \mathrm{~kb}$ of DNA, encompassing the entire Pth gene. The transcriptional unit spans $3.2 \mathrm{~kb}$ of genomic DNA and, analogous to the human PTH gene, it is interrupted by two introns. The deduced mRNA encodes the 115-amino acid precursor, preproPTH. Comparison of the murine preproPTH sequence with other mammalian forms of the protein shows it to be highly conserved and to share limited structural similarity to PTHrP at the amino-terminal region, a domain critical for binding and activation of their common receptor. Putative binding motifs for the transcription factors sex-determining region $Y$ gene product, transcriptional repressor CDP, hepatic nuclear factor $3 \beta$, GATA-binding factor 1, glucocorticoid receptor, SRY-related high mobility group box protein 5 and cAMP response element binding protein were identified in the $5^{\prime}$ flanking region of the Pth gene. When placed upstream of a reporter gene, these sequences failed to confer transcriptional regulation in response to $1,25(\mathrm{OH})_{2}$ vitamin $\mathrm{D}_{3}$, but responded positively to the addition of isoproterenol and forskolin. Mutational analysis identified a cAMP-response element in the Pth promoter.
\end{abstract}

Journal of Molecular Endocrinology (2002) 29, 193-203

\section{Introduction}

Parathyroid hormone (PTH) is the major peptide regulator of calcium homeostasis and is produced almost exclusively by parathyroid cells as a prepropeptide (Habener et al. 1984). It is the mature 84-amino acid form of the hormone, however, that is normally secreted in response to a decrease in serum calcium concentration. Structureactivity studies have shown that all the classic biological actions of PTH (stimulation of cAMP production, increase in calcium reabsorption, phosphaturia, bicarbonaturia, $1 \alpha$-hydroxylation of 25-hydroxyvitamin D and stimulation of bone resorption) reside in the $1-34$ region of the mature protein (Potts et al. 1982). All these bone and kidneyrelated functions of PTH are believed to be mediated by the type 1 PTH receptor (PTHR1) (Jüppner et al. 1991), a $G$ protein-coupled cell surface receptor that recognizes the amino-terminal region of PTH. This receptor possesses the unusual property of binding both PTH and the paracrine factor PTHrelated peptide (PTHrP) with nearly equal affinity. PTHrP was initially identified as the long-sought factor responsible for humoral hypercalcemia in patients with malignancy, and has come to be recognized as an important physiological agent that shares chemical structure and biological actions 
with PTH. However, it is distinct from PTH in many structural features and certain biological effects, particularly in fetal development and physiology (Strewler 2000). The capacity of the human PTHR 1 to bind both PTH and PTHrP is based on sequence similarity in the amino-terminal portion of these ligands.

Despite the overwhelming evidence for unique PTH action on the bone and kidney, effects in other tissues have also been reported. Thus PTH may contribute, along with PTHrP, to the growth and differentiation of cartilage, has profound hypotensive effects by relaxing resistance-type vessels, has a relaxant effect on gastrointestinal smooth muscle, and may participate in the regulation of calcium metabolism in the central nervous system (Fitzpatrick et al. 1992, Hock et al. 2002). Whether any or all of these functions, however, are actually mediated by circulating $\mathrm{PTH}$, or rather by locally produced PTHrP, remains speculative.

The cloning of the type $2 \mathrm{PTH}$ receptor (PTHR2), a second G protein-coupled cell surface receptor that binds only PTH (Usdin et al. 1995), has added a further degree of complexity. In contrast to PTHR1, which is distributed in virtually all tissues, PTHR2 is expressed mainly in the brain, pancreas, sperm, arterial and cardiac endothelium and vascular smooth muscle, and in a number of endocrine cells (Usdin et al. 1996, 1999a), suggesting unique actions for PTH at these sites, although the natural ligand for this receptor is likely to be the neuropeptide tuberoinfundibular peptide of 39 residues (TIP39), rather than PTH itself (Usdin et al. 1999b). Characterization of a third PTH receptor with specificity for the carboxyterminal region of PTH has also been reported in osteoblasts, rat parathyroid (PT-r3) cells, and osteocytes (Inomata et al. 1995, Divieti et al. 2001). It would seem, therefore, that several distinct properties could be attributed to PTH, probably mediated by a variety of receptors. Whether these new biological effects of PTH have potential physiological relevance remains to be determined.

With the intention of examining this issue in the intact organism, we have set out selectively to remove the Pth gene from the mouse genome, through the gene targeting approach. Mice carrying the Pth-null mutation can then be generated and studied for associated abnormalities. As a first step in generating Pth-null mice, we have isolated mouse recombinant genomic Pth clones and characterized the genomic organization, nucleotide sequence, and transcriptional regulation of the murine Pth gene.

\section{Materials and methods}

\section{Southern blot analysis of murine genomic DNA}

Genomic DNA $(10 \mu \mathrm{g})$, prepared from D3 mouse embryonic stem (D3 ES) cells (129/sV strain) (Doetschman et al. 1985), was digested with EcoRI. The DNA was fractionated on a $0.7 \%$ agarose gel and transferred onto a nitrocellulose membrane using standard procedures (Sambrook et al. 1989). Hybridization with an $\left[\alpha-{ }^{32} \mathrm{P}\right] \mathrm{dCTP}-\mathrm{labeled}$ random-primed human PTH cDNA probe (Vasicek et al. 1983) was carried out at $42{ }^{\circ} \mathrm{C}$ in $50 \%$ formamide, $4 \times$ saline sodium citrate $(\mathrm{SSC}$; $1 \times$ SSC: $300 \mathrm{mM} \mathrm{NaCl}, 30 \mathrm{mM}$ sodium citrate, pH 7·0), $2 \times$ Denhardt's solution, 10\% dextran sulfate, $100 \mu \mathrm{g} / \mathrm{ml}$ salmon sperm DNA (final concentration) for $16 \mathrm{~h}$. The blot was washed with $2 \times \mathrm{SSC} / 0 \cdot 1 \% \mathrm{SDS}$ for $30 \mathrm{~min}$ at room temperature and then with $0.2 \times \mathrm{SSC} / 0 \cdot 1 \% \mathrm{SDS}$ for $30 \mathrm{~min}$ at $50{ }^{\circ} \mathrm{C}$, before autoradiography was performed.

\section{Cloning of the mouse Pth gene}

A mouse genomic library constructed by cloning partial Sau3A digests of genomic DNA from D3 ES cells into the BamHI site of the phage lambdaDASH II (Stratagene, La Jolla, CA, USA) was kindly provided by $\mathrm{T}$ Doetschman. Approximately 700000 plaque-forming units (pfu) were screened with a ${ }^{32}$ P-labeled human PTH cDNA probe and two positive clones were plaque purified. The DNA from one positive clone was harvested using the plate lysis method and EcoRI fragments were further subcloned into pGEM-2 (Promega) for mapping and sequencing.

\section{Nucleotide sequence analysis}

The dideoxynucleotide method was used for sequencing both strands of the cloned DNA fragments (Sanger et al. 1977). Initially, oligonucleotide primers were synthesized corresponding to rat exonic sequences (Heinrich et al. 1984). All subsequent primers were derived from murine Pth 
sequences. Regions of poor clarity were verified by automated sequencing using an Applied Biosystems 373A DNA sequencer.

\section{Expression of mouse Pth mRNA}

Total RNA $(10 \mu \mathrm{g})$ from mouse thyroparathyroidal tissue was denatured in an aqueous solution consisting of $50 \%$ formamide $(\mathrm{v} / \mathrm{v})$ and $6 \%$ formaldehyde (v/v) and fractionated by electrophoresis through a $1 \cdot 2 \%$ agarose gel containing $6 \%$ formaldehyde. Four micrograms of RNA Millennium Markers (Ambion) were used as size markers in addition to the $28 \mathrm{~S}$ and $18 \mathrm{~S}$ rRNA. The fractionated RNAs were transferred onto a nitrocellulose membrane and the blot was hybridized with a ${ }^{32}$ P-labeled 500-bp HindIII-XhoI fragment encompassing exon 2 sequences of the murine Pth.

To identify additional sites of Pth expression, RT-PCR was performed using DNaseI-treated total RNA isolated using Trizol (Gibco) from mouse thyroparathyroidal tissue, bone, kidney, liver, lung, testis and thymus, as described previously (Gunther et al. 2000), except that, for Pth, annealing was at $61{ }^{\circ} \mathrm{C}$ and the corresponding primers were designed from the murine sequence. The following primers were used: Pth forward: 5'-ATGATGTCTGCAAACACGGTG GCT-3' and Pth reverse: 5'-CTGTCTAGAATAA ATCAGCATTTA-3'; hypoxanthine guanine phosphoribosyl transferase (Hprt) forward: 5'-AGCGA TGATGAACCAGGTTA-3'; Hprt reverse: 5'-GT TGAGAGATCATC-TCGACG-3'. The identity of amplified bands was confirmed by Southern blot analysis and direct DNA sequencing (thyroparathyroidal tissue and thymus).

\section{Generation of promoter constructs}

The $11.4 \mathrm{~kb}$ EcoRI DNA segment containing the murine Pth gene was digested with BamHI and the resulting $4.6 \mathrm{~kb}$ EcoRI-BamHI fragment encompassing 5'-flanking sequences and part of exon 1 was ligated into the EcoRI site in the Multiple Cloning Site (MCS) of the pSEAP2-Enhancer vector (control vector; Clontech), immediately upstream of the coding region of the secreted human placental alkaline phosphatase reporter gene $(4 \cdot 6 / \mathrm{pSEAP}-\mathrm{E})$. The EcoRI-BamHI segment was also used to obtain additional deletion fragments by digestion with KpnI, XhoI or ClaI, and ligating the DNA segments in the MCS of pSEAP2-Enhancer, thereby generating plasmids 3.8/pSEAP2-E, 2.7/pSEAP2-E, and $0 \cdot 2 /$ pSEAP2-E respectively.

Site-directed mutagenesis of the putative cAMP responsive element (CRE) in the promoter region was accomplished using the Chameleon Double-Stranded Site-Directed Mutagenesis Kit (Stratagene), with the SW3 selection primer (5'-GGTTTCTTAGTCGTGAGGTGGGACTT TTCGG-3') in conjunction with the sequencespecific mutation primer 5'-GCGAGAGAACGAG GAGGGAAATGTTGGTTAACAATAAAATAC-3' (bold letters indicate altered nucleotide residues). The mutated ClaI-BamHI fragment was ligated into the EcoRI site in the MCS of pSEAP2Enhancer, generating plasmid $0 \cdot 2 \mathrm{~m} / \mathrm{pSEAP} 2-\mathrm{E}$.

\section{Cell culture and transfection}

Rat pituitary GH4C1 and ROS17/2.8 cells were grown in Dulbecco's modified Eagle's medium supplemented with 10\% fetal calf serum (Gibco Life Technologies) in a humidified atmosphere with $5 \% \mathrm{CO}_{2}$ at $37^{\circ} \mathrm{C}$. Cells were transiently transfected in six-well plates, using Fugene6 (Roche Diagnostics) with $3 \mu \mathrm{g}$ /well pSEAP2-E-based promoter plasmids with appropriate amounts of carrier DNA (pcDNA3) to compensate for differences in vector size, and $1 \mu \mathrm{g} /$ well pcDNA3- $\beta$ Gal that directs expression of $\beta$-galactosidase. The latter was used to correct for transfection efficiency. In some experiments, cells were treated with isoproterenol $\left(1 \times 10^{-7} \mathrm{M}\right)$, forskolin $\left(1 \times 10^{-6} \mathrm{M}\right)$ or $1,25(\mathrm{OH})_{2}$ vitamin $\mathrm{D}_{3}\left(1 \times 10^{-8} \mathrm{M}\right) 18 \mathrm{~h}$ after transfection and then again the following day. Conditioned media samples were collected $48 \mathrm{~h}$ and $72 \mathrm{~h}$ after transfection, at which time cells were also harvested and alkaline phosphatase and $\beta$ galactosidase activities were determined according to the manufacturer's instructions.

\section{Statistical analysis}

Differences between treated and control samples derived from five independent experiments, each performed in triplicate, were analyzed by the Student's $t$-test and one-way analysis of variance using the software program GraphPad Prism, v3.0 (GraphPad Software, Inc., San Diego, CA, USA). 
A

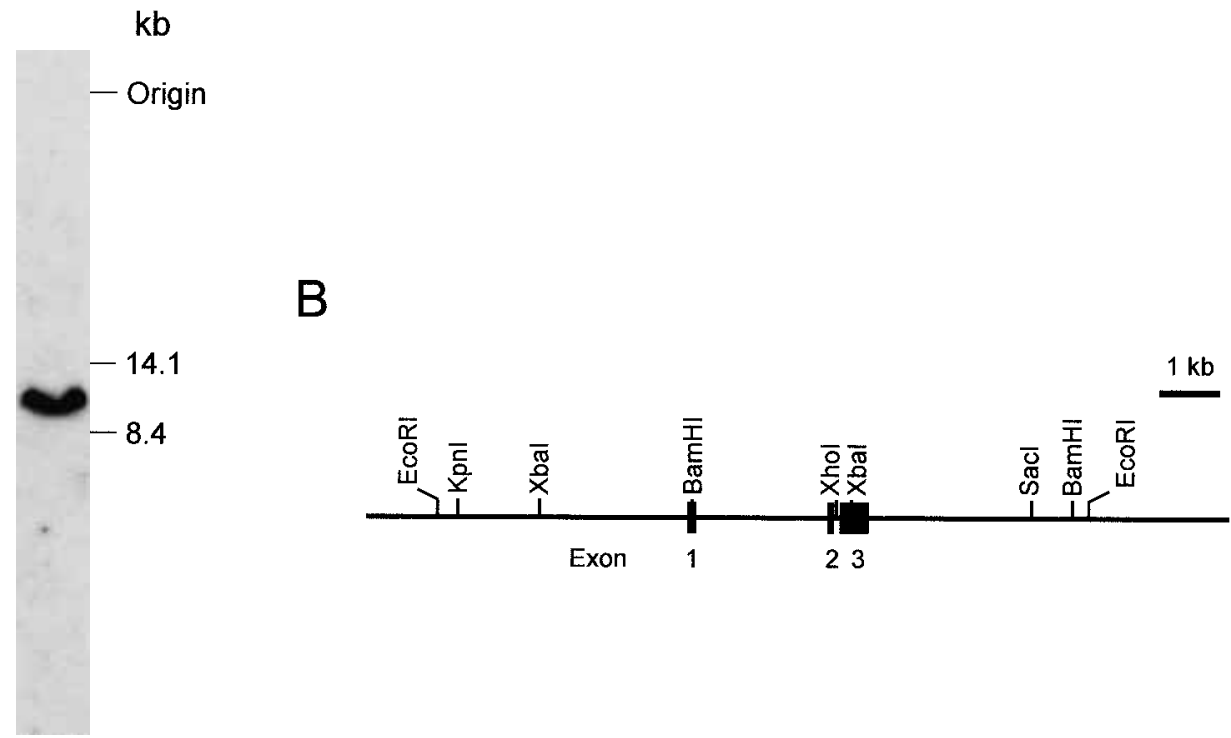

Figure 1 Southern blot analysis and genomic organization of mouse Pth. (A) Murine Pth is a single-copy gene. Genomic DNA $(10 \mu \mathrm{g})$ prepared from murine D3 ES cells was digested with EcoRI, fractionated on a $0.7 \%$ agarose gel, transferred onto a nitrocellulose membrane and probed with an $\left[\alpha^{-32} \mathrm{P}\right] \mathrm{dCTP}$-labeled random-primed human PTH cDNA probe. The position of the molecular weight markers (a BstEll digest of DNA) is indicated in kb.

(B) Restriction map of $\lambda-2$ bacteriophage insert containing the mouse Pth. The DNA from clone $\lambda-2$ was harvested using the plate lysis method and EcoRI fragments were further subcloned into pGEM-2 for mapping and sequencing. The black boxes correspond to the three exons.

All data are presented as mean \pm S.E. The value $P<0 \cdot 05$ was considered significant.

\section{Results}

\section{The murine Pth is a single-copy gene}

Southern blot analysis was used to determine the copy number of the Pth gene in the mouse genome. EcoRI-digested genomic DNA from D3 ES cells was fractionated on an agarose gel and transferred to a nitrocellulose membrane. Hybridization with a human PTH cDNA probe demonstrated a unique $11 \mathrm{~kb}$ EcoRI band (Fig. 1A), suggesting that the Pth gene exists as a single-copy gene in the murine genome.

\section{Cloning and analysis of the structural gene encoding PTH}

A mouse genomic library from D3 ES cells was screened with a ${ }^{32}$ P-labeled human PTH cDNA probe and two positive clones were plaque purified, each containing approximately $14 \mathrm{~kb}$ inserts. The DNA from one positive clone $(\lambda-2)$ was harvested using the plate lysis method and EcoRI fragments were further subcloned into pGEM-2 for mapping and sequencing. Characterization of one of these clones showed it to contain the entire mouse Pth gene (Fig. 1B). The transcriptional unit of murine Pth was located on an EcoRI restriction fragment of $11 \cdot 4 \mathrm{~kb}$, consistent with results of the Southern blot analysis.

\section{Genomic organization and deduced amino acid sequence}

Murine Pth was shown to span $3 \cdot 2 \mathrm{~kb}$ of genomic DNA (Fig. 1B) and to contain three exons interrupted by two introns (GenBank accession Nos AF066074 and AF066075). The assignment of intron-exon junctions was based on comparison with rat genomic and cDNA sequences and $5^{\prime}-3^{\prime}$ splice consensus sequences. All intron sequences immediately adjacent to the exons obey the GT/AG rule. Exon 1 encodes the $5^{\prime}$-untranslated 
A

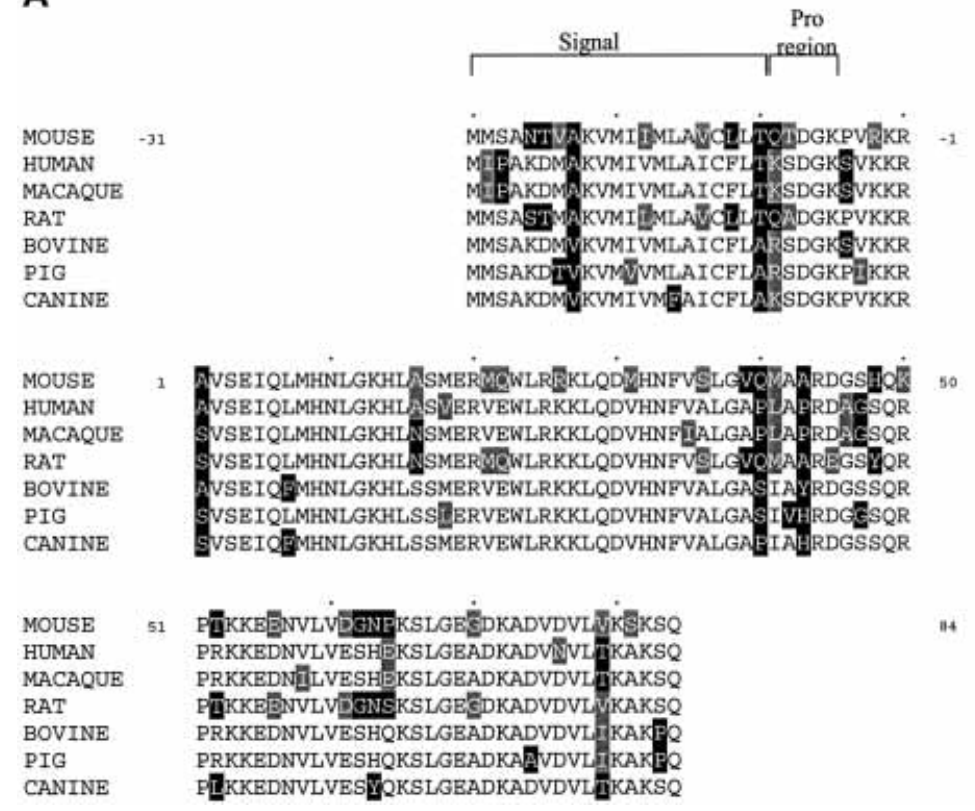

B

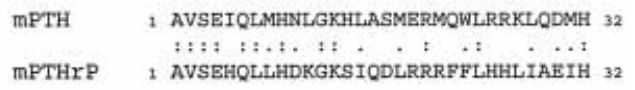

Figure 2 Sequence comparison of mammalian forms of preproPTH. (A) Amino acid sequence of murine preproPTH was deduced from the reported nucleotide sequence (GenBank accession Nos AF066074 and AF066075). Amino acids are represented by one-letter codes. Negative numbers signify prepro sequences and the mature PTH protein is keyed with positive numbers. Reported amino acid sequences of human (Vasicek et al. 1983), macaque (unpublished, Q9XT35), rat (Heinrich et al. 1984), bovine (Kronenberg et al. 1979), porcine (Sauer et al. 1974), and canine (Rosol et al. 1995) PTH are used. Residues conserved across most species are left unshaded, whereas somewhat conserved and highly variable residues have been highlighted by light and dark shading, respectively, using the BoxShade program (www.ch.embnet.org). (B) Comparison between amino-terminal amino acid sequences of murine PTH and PTHrP. Identities are indicated by one or two dots (sequence similarity, semi-conserved amino acid and sequence identity, conserved amino acid, respectively).

region $(U T R)$, whereas exon 2 encodes six nucleotides of the $5^{\prime}$-UTR and the prepro-coding region encompassing a pre (or signal) sequence of 25 amino acids and part of a basic propeptide of six amino acids. Exon 3 encodes the Lys-Arg prohormone cleavage site, the mature 84 amino acid peptide, and the $3^{\prime}-U T R$ of the gene containing the canonical motif AATAAA that serves as signal for polyadenylation of mRNAs.

From the complete nucleotide sequence of the presumed mRNA encoded by the mouse Pth, the amino acid sequence of the murine preproPTH was deduced. Alignment of full-length amino acid sequences of mouse and other mammalian preproPTH forms is shown in Fig. 2A. A high level of conservation is evident among the various species in the prepro sequence, specifically amino acids -16 to $-14(\mathrm{~A}-\mathrm{V} / \mathrm{I}-\mathrm{C})$ in the signal sequence portion and the basic residues (KR) at position -2 and -1 recognized by prohormone convertases that cleave the pro region from the mature peptide. The amino-terminal $1-34$ portion, a region known to be responsible for the classic biological actions of PTH, displays an equally high degree of sequence identity. This high sequence identity is also shared in part by the corresponding domain of the mouse PTHrP (Mangin et al. 1990). Here, nine of the first 13 amino acids are identical, whereas in the region 14-32, only three residues are the same, followed by prominent structural divergence (Fig. 2B). Interestingly, there is also marked conservation of amino acid composition from one species to another in the carboxyterminal region of PTH, suggesting potential biological functionality for this part of the protein.

The mouse sequence contains five substitutions (K-3R, K26R, V31M, R50K and A81S) in residues that have been conserved in all other mammalian preproPTH species examined. Overall, these changes represent conservative amino 
A

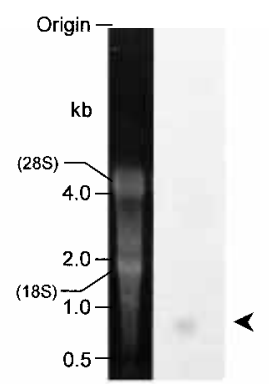

B

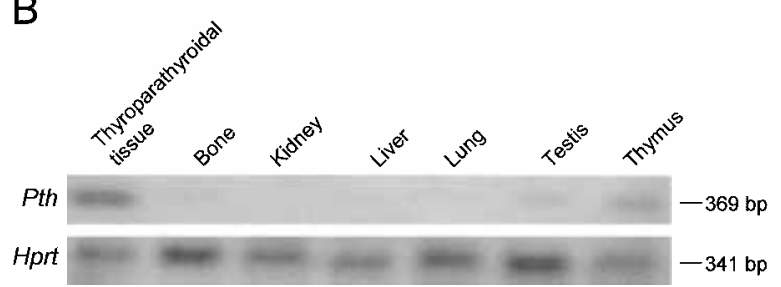

Figure 3 Expression of the murine Pth transcript. (A) Total RNA from mouse thyroparathyroidal tissue $(10 \mu \mathrm{g})$ was electrophoresed on a $1.2 \%$ agarose gel, blotted onto a nitrocellulose membrane filter and hybridized with a ${ }^{32} \mathrm{P}$-labeled probe containing exon 2 sequences of the murine $P$ th. The relative mobilities of RNA molecular weight markers and the $28 \mathrm{~S}$ and $18 \mathrm{~S}$ ribosomal RNAs are shown on the left of the panel. Arrowhead indicates the band corresponding to the murine Pth transcript. (B) RT-PCR and Southern blot analysis of $P$ th transcripts in various murine tissues. Hprt expression was determined as control for the reverse transcription reaction. acid substitutions. Compared with its human orthologue, the putative mature mouse PTH protein exhibits a $70 \%$ sequence identity and $85 \%$ sequence similarity at the amino acid level (data not shown).

\section{Expression of the mouse Pth mRNA}

To determine the size of murine Pth mRNA, total RNA from mouse thyroparathyroidal tissue was subjected to electrophoresis on agarose gel, transferred to nitrocellulose membrane filter and hybridized to the labeled HindIII-XhoI fragment encompassing exon 2 of the mouse gene. As shown in Fig. 3A, the probe hybridized with a single transcript of $\sim 800 \mathrm{bp}$. Thus a single mRNA transcript is derived from the murine Pth gene. Its size is consistent with the predicted Pth cDNA and comparable to that reported for the rat Pth mRNA (Heinrich et al. 1984). Using the more sensitive method of RT-PCR followed by Southern blot analysis, Pth transcripts were also detected in the thymus, as previously reported (Gunther et al. 2000), and in the testis (Fig. 3B).

\section{The Pth promoter region}

With the aim of identifying potential regulatory elements in the $5^{\prime}$ flanking region of the mouse Pth

Figure 4 Analysis of the Pth promoter. (A) Putative transcriptional control elements in the murine (GenBank accession No. AF066074) and rat (GenBank accession No. K01267) Pth promoter. Putative cis-acting regulatory sequences are displayed in bold typeface. Consensus sequences for the various response elements are shown above the corresponding sequence, with arrows indicating orientation. The asterisks represent matching nucleotides. HNF-3beta, hepatic nuclear factor 3 $\beta$; GATA-1, GATA-binding factor 1; SRY, sex-determining region Y gene product; CDP, transcriptional repressor CDP; GR, glucocorticoid receptor; CRE-BP, cAMP response element binding protein; Sox-5, SRY-related high mobility group box protein 5; TFIID (TBP), TATA binding protein. $W=A$ or $T ; M=A$ or $C ; N=A$ or $\mathrm{C}$ or $\mathrm{G}$ or $\mathrm{T} ; \mathrm{Y}=\mathrm{C}$ or $\mathrm{T} ; \mathrm{R}=\mathrm{A}$ or $\mathrm{G}$. Sequences outlined with the gray box represent the putative response element reported to mediate transcriptional repression of human $P T H$ in response to $1,25(\mathrm{OH})_{2}$ vitamin $\mathrm{D}_{3}$. The murine and rat sequences deviate from the corresponding human sequence by one nucleotide. (B) Transcriptional regulation of $P$ th. A schematic representation of the promoter-reporter gene fusion constructs used is shown on the left side. Black boxes indicate the corresponding genomic DNA fragments, and the gray box represents the SEAP sequence. Site-directed mutagenesis of the CRE in the Clal-BamHI fragment is also depicted. Fold-stimulation in alkaline phosphatase activity over the promoterless SEAP2-E vector (control) is shown on the right, corrected for transfection efficiency by normalizing alkaline phosphatase activity of the experimental plasmid for $\beta$-galactosidase activity obtained from a co-transfected internal control plasmid. On the top panel, gray and open bars indicate fold stimulation of promoter fragments in the absence and presence of $1,25(\mathrm{OH})_{2}$ vitamin $\mathrm{D}_{3}$ respectively. On the bottom panel, filled and open bars indicate fold stimulation in the absence and presence of isoproterenol $\left(1 \times 10^{-7} \mathrm{M}\right)$, respectively. Results shown are the mean \pm S.E. from five independent experiments, each performed in triplicate. $\# P<0.05$, for difference between 0.2/pSEAP2-E basal activity and that of each of the other promoter constructs; ${ }^{*} P<0.01$, for difference between isoproterenol-stimulated and -unstimulated promoter fragment activity. 
A

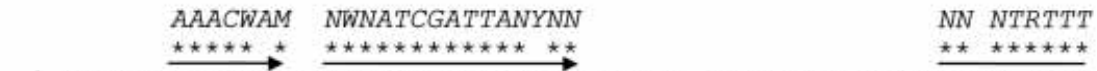

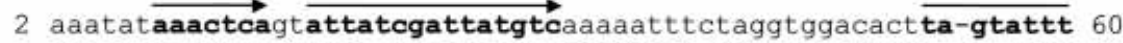
111111111 111111111 11111 1111 | 111111 1111 11111 | 1111 145 aatataaatcagtatcatggattacgtcagattttctaagtggttacttaagcattt 204 SRY CDP HNF-3beta

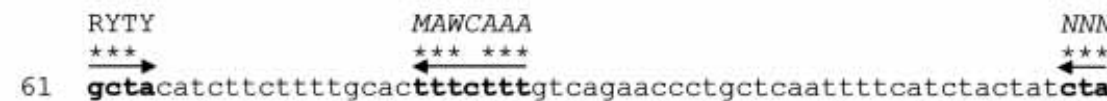

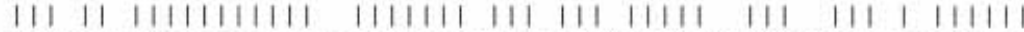

205 gctgcaacttctttgcagattctttgccagcaccttgctcttttgaatccattatcta 264 SRY

NRATAGWCNN

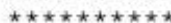

TGTTCT

$\star \star \star \star \star \star * \star *$

121 gttatctgaaactt tagaggagtgggcaccaccccatgagggtatgtggctgttctgat- 179

1111111111111111111111111111 |1। 111111111 11111111111111

265 agtatctgaaactttagaggagtgggcaccgcccgatgagggtaggtggctgttctgatt 324 GATA-1

GR

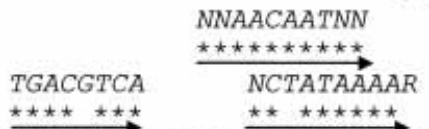

180 cctgtgattgagagccagagaaccaggagtgacatcatccttaacaataaatactcctc 239 |11 |11111111 |111111111111 |111111111111 |111111111111111

325 cctatgattgagaaccagagaaccaggcatgacatcatccttcccaataaaatactcctc 384 CRE-BP TFIID Sox -5

240 ttggtgagcaaaaagc 255

11111111111111

385 ttggtgagcaaaaggc 400

B

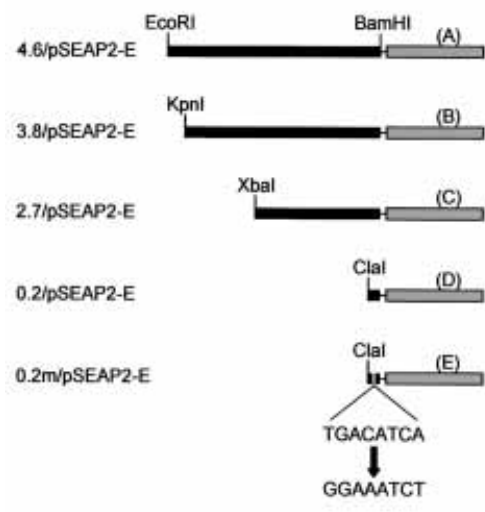

pSEAP2-E
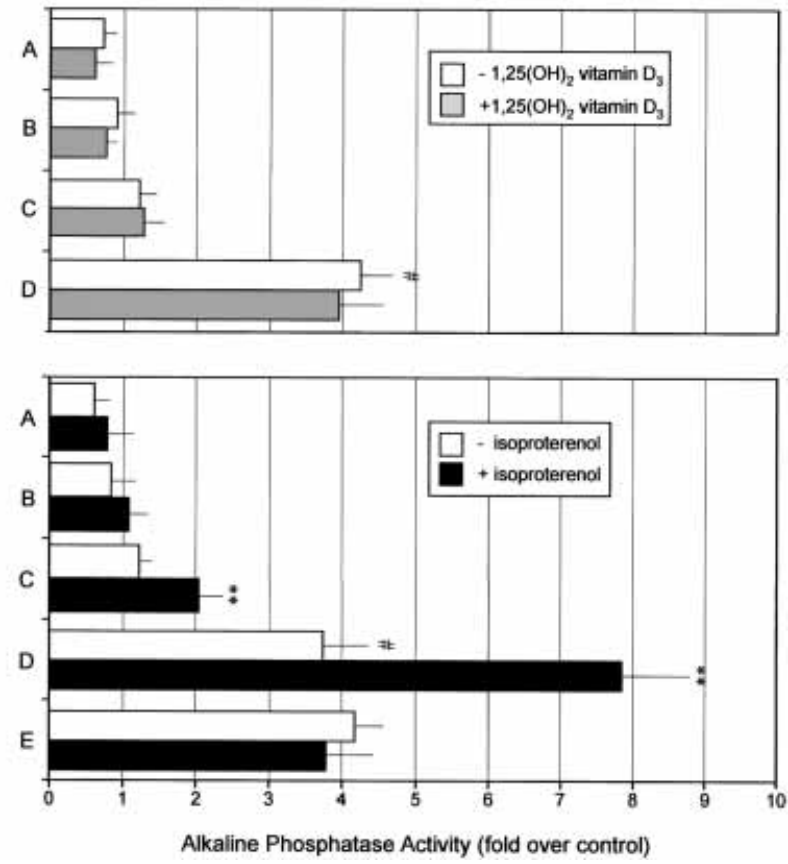

www.endocrinology.org

Journal of Molecular Endocrinology (2002) 29, 193-203 
gene, a $255 \mathrm{bp}$ region upstream of the main transcription start site was analyzed using TFSEARCH (Kyoto University, Kyoto, Japan) for putative transcription factor binding sites. Several transcriptional control elements were identified in the Pth promoter region, including a TATA binding protein (TBP; TFIID) element in the $-33 \mathrm{bp}$ to $-24 \mathrm{bp}$ region, corresponding to the TATA-like box. Possible recognition and binding sites for transcription factors transcriptional repressor CDP (CDP), hepatic nuclear factor $3 \beta$ (HNF-3 $\beta$ ), GATA-binding factor 1 (GATA-1), sex-determining region $\mathrm{Y}$ gene product (SRY) and SRY-related high mobility group box protein 5 (Sox-5) were also present in the promoter region, as indicated in Fig. 4A. Examination of this sequence also revealed the presence of one glucocorticoid response element (GRE) half-site, but not a canonical GRE, and a sequence that resembles the canonical GRE.

To identify functional positive or negative cisacting regulatory elements in the $5^{\prime}$-flanking region of the Pth gene, DNA sequences (EcoRI at $-4.6 \mathrm{~kb}$, $\mathrm{KpnI}$ at $-3.8 \mathrm{~kb}$, XbaI at $-2.7 \mathrm{~kb}$, or ClaI at $-0.2 \mathrm{~kb}$, to the BamHI site at position +65$)$ were cloned immediately upstream of the coding region of the secreted human placental alkaline phosphatase reporter gene in the SEAP2-Enhancer vector. Promoter transcriptional activity was examined after transient transfection in rat pituitary GH4C1 cells by measuring alkaline phosphatase activity in the conditioned medium. Sequential deletions from this region in the $5^{\prime}$ to $3^{\prime}$ direction resulted in a stepwise increase in Pth promoter transcriptional activity (Fig. 4B). Maximal levels were observed with the $0 \cdot 2 \mathrm{~kb}$ ClaI-BamHI fragment compared with the other constructs $(5 \cdot 8$-fold increase in activity over the 4·6-kb EcoRI-BamHI segment), suggesting that inhibitory sequences that regulate cell-specific gene expression probably localize to the more $5^{\prime}$ regions of the promoter.

We next examined the transcriptional regulation of the Pth promoter fragments by $1,25(\mathrm{OH})_{2}$ vitamin $\mathrm{D}_{3}$ after its addition to the culture medium. As shown, 1,25 $(\mathrm{OH})_{2}$ vitamin $\mathrm{D}_{3}$ did not decrease Pth promoter activity with all of the constructs tested (Fig. 4B). Similar results were observed after transfection of the promoter fragments in ROS $17 / 2 \cdot 8$ cells and persisted even after co-transfection of the vitamin D receptor (VDR) cDNA in GH4C1 cells (results not shown).
In contrast, addition of isoproterenol $\left(1 \times 10^{-7} \mathrm{M}\right)$ or forskolin $\left(1 \times 10^{-6} \mathrm{M}\right)$ to the culture medium increased promoter transcriptional activity, suggesting the presence of a CRE in this region. A sequence resembling the canonical CRE (5'-TGACGTCA-3') localizes at position -47 to -40 and is also present in the human, rat and bovine sequences. In $\operatorname{ROS} 17 / 2 \cdot 8$ and GH4C1 cells, addition of isoproterenol to the conditioned medium resulted in significant increases in the transcriptional activity of the XbaI-BamHI and specifically the ClaI-BamHI ( $2 \cdot 1$-fold) Pth promoter fragments. Similar results were observed after the addition of forskolin (data not shown). Finally, site-directed mutagenesis of this sequence (TGA CATCA to GGAAATCT) totally abrogated the capacity of the ClaI-BamHI fragment to increase the level of alkaline phosphatase activity in the conditioned medium in response to isoproterenol (Fig. 4B) or forskolin (data not shown), indicating that this sequence is a functional CRE.

\section{Discussion}

In this study, we have cloned and characterized the murine Pth gene by determining its genomic organization, nucleotide sequence and transcriptional regulation. The structural organization of the mouse gene is identical to that reported for the human (Vasicek et al. 1983) and rat genes (Heinrich et al. 1984), with complete conservation of exonintron structures amongst species. Likewise, the open reading frame of the putative mouse $P$ th gene is contained in two exons and encodes a protein of 115 amino acids that shares a high degree of sequence identity with other mammalian homologues. The sequence similarity is apparent in most regions of the protein, including the prepropeptide, and the amino- and carboxy-terminal portions. In the prepropeptide, it encompasses: residues -16 to $-14(\mathrm{~A}-\mathrm{V} / \mathrm{I}-\mathrm{C})$ in the signal sequence that contain a cysteine residue previously shown to be critical for correct targeting of the nascent polypeptide chain to the endoplasmic reticulum (Karaplis et al. 1995); the cleavage site for signal peptidase enzyme at residues -8 to -6 (DGK); and the basic residues at position -2 and -1 (KR) recognized by the prohormone convertases furin (paired basic amino acid cleaving enzyme (PACE)) and PC7, a member of the proprotein convertase $(\mathrm{PG})$ family, 
both of which cleave the pro region from the mature peptide (Hendy et al. 1995, Canaff et al. 1999).

In the amino-terminal domain, the high degree of conservation and sequence similarity with the corresponding region of PTHrP emphasize the pivotal importance of this part of the protein in binding and activation of PTHR 1 and underscore the likelihood of a biological overlap between the two ligands and their common receptor. Evidence for an in vivo functional overlap between PTH and PTHrP has come primarily from gene targeting studies. Mice homozygous for Pthrp gene ablation are born alive (meeting Mendelian expectations), but die soon after birth because of a multitude of skeletal deformities that arise as a consequence of diminished proliferation and inappropriate differentiation of chondrocytes in the developing skeleton (Amizuka et al. 1994, Karaplis et al. 1994). In contrast, animals homozygous for the Pthr1-null allele exhibit a more severe phenotype characterized by embryonic lethality (Lanske et al. 1996). A likely explanation for the early demise of the receptor-null animals may stem from the ability of circulating PTH to compensate partly for the absence of PTHrP, but not for that of the receptor. Our finding of amino-terminal sequence similarity between the two murine proteins now adds further support to this concept.

Like the amino-terminus, the carboxy-terminal sequence of PTH is highly conserved amongst species, which adds further support to the intriguing speculation that this region of the protein may also serve distinct physiological functions. Circulating carboxy-terminal PTH peptides, previously assumed to be biologically inert, are generated by peripheral metabolism of intact PTH or are directly secreted, in a calcium-dependent manner, by the parathyroid glands. Interestingly, PTH 7-84 was recently shown to inhibit the calcemic actions of $\mathrm{PTH}(1-84)$ and $\mathrm{PTH}(1-34)$ in parathyroidectomized animals at doses much lower than would be predicted to antagonize either hormonal form effectively at the level of the PTHR1 (Slatopolsky et al. 2000, NguyenYamamoto et al. 2001). This anticalcemic effect of $\operatorname{PTH}(7-84)$ in vivo is a consequence of impaired osteoclast differentiation and is probably mediated via receptors distinct from PTHR 1 and presumably specific for PTH carboxyl fragments on bone cells (Divieti et al. 2002).
In view of the fact that no parathyroid cell line exists that could be used to study the regulation of $P$ th gene transcription in a setting that would reflect the in vivo regulation pattern, we had to restrict our studies to heterologous cell lines (Demay et al. 1992). In general, sequences upstream of a gene contain regulatory sequences in addition to sequences that determine tissue expression specificity. Arnold's group has shown that $4 \mathrm{~kb}$ of genomic DNA upstream from the human PTH gene was sufficient to direct parathyroid glandspecific expression in transgenic mice (Imanishi et al. 2001). In our study, progressive $5^{\prime}$ to $3^{\prime}$ deletions from this region resulted in increased promoter transcriptional activity when expressed in rat pituitary GH4Cl cells, with the $0.2 \mathrm{~kb}$ ClaI-BamHI fragment showing a maximal increase in activity over the $4 \cdot 6-\mathrm{kb}$ EcoRI-BamHI DNA segment. Conceivably, sequences in the 5'-flanking region of the murine Pth gene determine parathyroid cell-specific gene expression and, after their deletion, levels of reporter gene expression increase in the heterologous cell line.

The present study also shows that Pth gene expression is further regulated by agents that increase intracellular cAMP concentrations - either isoproterenol, a $\beta$-adrenergic agonist for which the receptor is coupled to adenylate cyclase in GH4C1 cells (Gordeladze 1990), or forskolin, a plant diterpene, known to stimulate adenylate cyclase. A sequence that resembles the canonical CRE but deviates in one position in the center of the recognition motif is found at position -47 . This element, shown to be functional and to confer cAMP-responsiveness, is also present in the rat, bovine and human PTH promoters (Rupp et al. 1990). It could be speculated that the modest (approximately two-fold) effect of isoproterenol or forskolin on the promoter activity is due to the deviation from the consensus sequence (TGACGTCA) in the center of the putative CRE (TGACATCA). In other systems, however, this element does contribute to a dramatic activation of promoter activity. Alternatively, elements in its vicinity in the Pth promoter may exert effects that partly obscure the cAMP induction mechanism. At present, little is known about the connection between the CRE and Pth expression, but stimulators of protein kinase A have been reported to increase Pth mRNA levels in bovine parathyroid cells (Moallem et al. 1995). 
It is, perhaps, somewhat perplexing that our studies did not identify DNA sequences that confer vitamin D-mediated regulation of Pth promoter activity. Demay and colleagues (Demay et al. 1992, Mackey et al. 1996) have reported that a single copy of the motif AGGTTCA, homologous to the motifs repeated in the up-regulatory $1,25(\mathrm{OH})_{2}$ vitamin $\mathrm{D}_{3}$-response element in the rat and human osteocalcin genes, mediates transcriptional repression of $P$ th in response to $1,25(\mathrm{OH})_{2}$ vitamin $\mathrm{D}_{3}$. This sequence, however, is not preserved across species and is absent from the $5^{\prime}$-flanking region of the mouse and rat Pth genes. In contrast, others have demonstrated that two imperfect repeats, GGGTCA and GGGTGT, which are separated by a 3-bp spacer in the avian PTH gene, are responsible for binding the $1,25(\mathrm{OH})_{2}$ vitamin $\mathrm{D}_{3}$ receptor and mediating negative regulation of gene transcription (Liu et al. 1996). Whether sequences further upstream from the EcoRI site (4.6 kb) confer vitamin D-dependent gene repression of the murine Pth gene remains to be determined.

Finally, the sequence TGTTCT at bases -85 to - 80, which corresponds to the high-affinity GRE consensus half-site, is present in a number of glucocorticoid-responsive genes and has been shown to impart dexamethasone responsiveness to homologous promoter fragments (Chandrasekhar et al. 1999). Treatment with dexamethasone has been reported to increase PTH mRNA in human parathyroid cells in vitro (Peraldi et al. 1990). Further studies will be required to confirm the role of this individual GRE in the glucocorticoid responsiveness of the $P$ th promoter.

In summary, we have cloned from a D3 ES cell genomic library an $11.4 \mathrm{~kb}$ EcoRI DNA fragment encompassing the entire murine Pth. This study has made possible the description of the gene structure and of the structural and functional characteristics of its promoter sequence. These observations provide the bases for more detailed investigation of the molecular mechanisms controlling expression of the Pth gene in parathyroid cells, and for the targeted disruption of Pth in embryonic stem cells. The production of mice null for the $P$ th gene and double-null for the Pth/Pthrp genes will help clarify the potential for functional overlap between two ligands, PTH and PTHrP, and their common receptor, and shed light on as yet unrecognized roles for PTH in normal physiology.

\section{Acknowledgements}

We thank $\mathrm{J} \mathrm{H}$ White for providing us with $1,25(\mathrm{OH})_{2}$ vitamin $\mathrm{D}_{3}$ and the VDR cDNA. This work was supported by grants from the Canadian Institutes of Health Research (CIHR) and Canadian Arthritis Network. A C K is the recipient of a CIHR Scientist Award.

\section{References}

Amizuka N, Henderson JE, Warshawsky H, Goltzman D \& Karaplis AC 1994 Parathyroid hormone-related peptide (PTHrP)-depleted mice show abnormal epiphyseal cartilage development and altered endochondral bone formation. Fournal of Cell Biology 126 $1611-1623$

Canaff L, Bennett HP, Hou Y, Seidah NG \& Hendy GN 1999 Proparathyroid hormone processing by the proprotein convertase-7: comparison with furin and assessment of modulation of parathyroid convertase messenger ribonucleic acid levels by calcium and 1,25-dihydroxyvitamin D. Endocrinology 140 3633-3642.

Chandrasekhar S, Souba WW \& Abcouwer SF 1999 Identification of glucocorticoid-responsive elements that control transcription of rat glutamine synthetase. American fournal of Physiology 276 L319-L331.

Demay MB, Kiernan MS, DeLuca HF \& Kronenberg HM 1992 Sequences in the human parathyroid hormone gene that bind the 1,25-dihydroxyvitamin D3 receptor and mediate transcriptional repression in response to 1,25-dihydroxyvitamin D3. PNAS $\mathbf{8 9}$ 8097-8101.

Divieti P, Inomata N, Chapin K, Singh R, Juppner H \& Bringhurst FR 2001 Receptors for the carboxyl-terminal region of PTH(1-84) are highly expressed in osteocytic cells. Endocrinology 142 916-925.

Divieti P, John MR, Juppner H \& Bringhurst FR 2002 Human PTH-(7-84) inhibits bone resorption in vitro via actions independent of the type $1 \mathrm{PTH} / \mathrm{PTHrP}$ receptor. Endocrinology $143171-176$.

Doetschman TC, Eistetter H, Katz M, Schmidt W \& Kemler R 1985 The in vitro development of blastocyst-derived embryonic stem cell lines: formation of visceral yolk sac, blood islands and myocardium. Fournal of Embryology and Experimental Morphology 87 $27-45$.

Fitzpatrick LA, Coleman DT \& Bilezikian JP 1992 The target tissue actions of parathyroid hormone. In Disorders of Bone and Mineral Metabolism, pp 123-148. Eds FC Coe \& MJ Favus. New York: Raven Press.

Gordeladze JO 1990 The pharmacodynamic action of the cyclic AMP phosphodiesterase inhibitor rolipram on prolactin producing rat pituitary adenoma (GH4C1) cells. Bioscience Reports $\mathbf{1 0}$ 375-388.

Gunther T, Chen ZF, Kim J, Priemel M, Rueger JM, Amling M, Moseley JM, Martin TJ, Anderson DJ \& Karsenty G 2000 Genetic ablation of parathyroid glands reveals another source of parathyroid hormone. Nature 406 199-203.

Habener JF, Rosenblatt M \& Potts Jr JT 1984 Parathyroid hormone: biochemical aspects of biosynthesis, secretion, action, and metabolism. Physiological Reviews 64 985-1053.

Heinrich G, Kronenberg HM, Potts Jr JT \& Habener JF 1984 Gene encoding parathyroid hormone: nucleotide sequence of the rat gene and deduced amino acid sequence of rat preproparathyroid hormone. Fournal of Biological Chemistry 259 3320-3329. 
Hendy GN, Bennett HP, Gibbs BF, Lazure C, Day R \& Seidah NG 1995 Proparathyroid hormone is preferentially cleaved to parathyroid hormone by the prohormone convertase furin. A mass spectrometric study. Fournal of Biological Chemistry 270 9517-9525.

Hock JM, Fitzpatrick LA \& Bilezikian JP 2002 Actions of parathyroid hormone. In Principles of Bone Biology, edn 2, pp 463-481. Eds JP Bilezikian, LG Raisz \& GA Rodan. New York: Academic Press.

Imanishi Y, Hosokawa Y, Yoshimoto K, Schipani E, Mallya S, Papanikolaou A, Kifor O, Tokura T, Sablosky M, Ledgard F, Gronowicz G, Wang TC, Schmidt EV, Hall C, Brown EM, Bronson R \& Arnold A 2001 Primary hyperparathyroidism caused by parathyroid-targeted overexpression of cyclin D1 in transgenic mice. Fournal of Clinical Investigation 107 1093-1102.

Inomata N, Akiyama M, Kubota N \& Jüppner H 1995 Characterization of a novel parathyroid hormone (PTH) receptor with specificity for the carboxyl-terminal region of PTH-(1-84). Endocrinology $1364732-4740$.

Jüppner H, Abou-Samra A-B, Freeman M, Kong X-F, Schipani E, Richards J, Kolakowski Jr LF, Hock J, Potts Jr JT, Kronenberg HM \& Segre GV 1991 A G protein-linked receptor for parathyroid hormone and parathyroid hormone-related peptide. Science 254 1024-1026.

Karaplis AC, Luz A, Glowacki J, Bronson RT, Tybulewicz VLJ, Kronenberg HM \& Mulligan RC 1994 Lethal skeletal dysplasia from targeted disruption of the parathyroid hormone-related peptide (PTHrP) gene. Genes and Development 8 277-289.

Karaplis AC, Lim SK, Baba H, Arnold A \& Kronenberg HM 1995 Inefficient membrane targeting, translocation, and proteolytic processing by signal peptidase of a mutant preproparathyroid hormone protein. Fournal of Biological Chemistry 270 1629-1635.

Kronenberg HM, McDevitt BE, Majzoub JA, Nathans J, Sharp PA, Potts Jr JT \& Rich A 1979 Cloning and nucleotide sequence of DNA coding for bovine preproparathyroid hormone. PNAS 76 4981-4985.

Lanske B, Karaplis AC, Lee K, Luz A, Vortkamp A, Pirro A, Karperien M, Defize LH, Ho C, Mulligan RC, Abou-Samra AB, Juppner H, Segre GV \& Kronenberg HM 1996 PTH/PTHrP receptor in early development and Indian hedgehog-regulated bone growth. Science 273 663-666.

Liu SM, Koszewski N, Lupez M, Malluche HH, Olivera A \& Russell J 1996 Characterization of a response element in the 5 '-flanking region of the avian (chicken) PTH gene that mediates negative regulation of gene transcription by 1,25-dihydroxyvitamin D3 and binds the vitamin D3 receptor. Molecular Endocrinology 10 206-215.

Mackey SL, Heymont JL, Kronenberg HM \& Demay MB 1996 Vitamin $\mathrm{D}$ receptor binding to the negative human parathyroid hormone vitamin D response element does not require the retinoid x receptor. Molecular Endocrinology 10 298-305.

Mangin M, Ikeda K \& Broadus AE 1990 Structure of the mouse gene encoding the parathyroid hormone-related peptide. Gene $\mathbf{9 5}$ 195-202.

Moallem E, Silver J \& Naveh-Many T 1995 Regulation of parathyroid hormone messenger RNA levels by protein kinase A and $\mathrm{C}$ in bovine parathyroid cells. Fournal of Bone and Mineral Research 10 447-452.
Nguyen-Yamamoto L, Rousseau L, Brossard JH, Lepage R \& D'Amour P 2001 Synthetic carboxyl-terminal fragments of parathyroid hormone $(\mathrm{PTH})$ decrease ionized calcium concentration in rats by acting on a receptor different from the PTH/PTH-related peptide receptor. Endocrinology 142 1386-1392.

Peraldi MN, Rondeau E, Jousset V, el M'Selmi A, Lacave R, Delarue F, Garel JM \& Sraer JD 1990 Dexamethasone increases preproparathyroid hormone messenger RNA in human hyperplastic parathyroid cells in vitro. European Fournal of Clinical Investigation 20 392-397.

Potts Jr JT, Kronenberg HM \& Rosenblatt M 1982 Parathyroid hormone: chemistry, biosynthesis, and mode of action. Advances in Protein Chemistry 35 323-339.

Rosol TJ, Steinmeyer CL, McCauley LK, Gröne A, De Wille JW \& Capen CC 1995 Sequences of the cDNAs encoding canine parathyroid hormone-related protein and parathyroid hormone. Gene 160 241-243.

Rupp E, Mayer H \& Wingender E 1990 The promoter of the human parathyroid hormone gene contains a functional cyclic AMP-response element. Nucleic Acids Research 18 5677-5683.

Sambrook J, Fritsch EF \& Maniatis T 1989 In Molecular Cloning. A Laboratory Manual, edn 2. Cold Spring Harbor: Cold Spring Harbor Laboratory Press.

Sanger F, Nicklen S \& Coulson AR 1977 DNA sequencing with chain-terminating inhibitors. PNAS 74 5463-5467.

Sauer RT, Niall HD, Hogan ML, Keutmann HT, O'Riordan JLH \& Potts Jr TJ 1974 The amino acid sequence of porcine parathyroid hormone. Biochemistry 13 1994-1999.

Slatopolsky E, Finch J, Clay P, Martin D, Sicard G, Singer G, Gao P, Cantor T \& Dusso A 2000 A novel mechanism for skeletal resistance in uremia. Kidney International $\mathbf{5 8}$ 753-761.

Strewler GJ 2000 The physiology of parathyroid hormone-related protein. New England Fournal of Medicine 342 177-185.

Usdin TB, Gruber C \& Bonner TI 1995 Identification and functional expression of a receptor selectively recognizing parathyroid hormone, the PTH2 receptor. Fournal of Biological Chemistry 270 15455-15458.

Usdin TB, Bonner TI, Harta G \& Mezey E 1996 Distribution of parathyroid hormone-2 receptor messenger ribonucleic acid in rat. Endocrinology 137 4285-4297.

Usdin TB, Hilton J, Vertesi T, Harta G, Segre G \& Mezey E 1999a Distribution of parathyroid hormone 2 receptor in rat: immunolocalization reveals expression by several endocrine cells. Endocrinology $1403363-3371$.

Usdin TB, Hoare SR, Wang T, Mezey E \& Kowalak JA 19996 TIP39: a new neuropeptide and PTH2-receptor agonist from hypothalamus. Nature Neuroscience 2 941-943.

Vasicek TJ, McDevitt BE, Freeman MW, Fennick BJ, Hendy GN, Potts Jr JT, Rich A \& Kronenberg HM 1983 Nucleotide sequence of the human parathyroid hormone gene. PNAS 80 2127-2131.

Received in final form 14 June 2002 Accepted 14 June 2002 